\title{
高品質 $\mathrm{SiGe}$ 結晶の
}

\section{育成と基礎物性の解明}

\section{米 永一 郎*}

\section{1. はじめに}

シリコンとゲルマニウムは全組成域でシリコンゲルマニウ ム $\mathrm{Si}_{x} \mathrm{Ge}_{1-x}$ ( $x$ は $\mathrm{Si}$ 組成), またはゲルマニウムシリコン $\mathrm{Ge}_{1-x} \mathrm{Si}_{x}$ と呼ばれる, ダイヤモンド構造の固溶体(混晶)を形 成する.さらに炭素 $\mathrm{C}$ も固溶させた $\mathrm{SiGeC}$ も含め, 格子定 数とバンドギャップの差異を利用・制御する工学用材料とし て注目されている. その格子定数は組成 $x$ によって Si から Ge までの間で 0.543 から $0.566 \mathrm{~nm}$ まで約 $4 \%$ Vegard 則 に従ってほぼ線形に変化する. SiGeのバンド構造は, 価電 子帯の最大エネルギー位置は $\Gamma$ 点であるが, 組成 $x か ゙ 0.15$ ま での範囲では伝導電子帯の最小エネルギー位置は $L$ 点にあ って $\mathrm{Ge}$ 的電子的特性を， $x$ が 0.15 以上では $X$ 点にあって $\mathrm{Si}$ 的特性を示す.バンドギャップは $\mathrm{Si}$ の $1.1 \mathrm{eV}$ から $\mathrm{Ge}$ の $0.72 \mathrm{eV}$ まで変化するが, $x=0.15$ で明瞭な折れ曲がりを示 す. 特に近年, 物理的な限界に近いとされる Si 電子デバイ スの高速化に向けた開発として，ヘテロエピタキシャル成長 において SiGe と Si を接合させた際に界面で生じるひずみ を利用すると電荷の移動度を向上させることができるため, ひずみ制御工学の観点でも注目されている，また，価電子带 の最大エネルギー位置では軽いホールと重いホールとの縮退 がとける.これらの特徵から， Si 基板上に成長させて圧縮 ひずみを導入した $\mathrm{SiGe}$ 薄膜ではホールの移動度が向上する ことを利用した HBT 型デバイスが，一方ひずみを除いて緩 和させた $\mathrm{SiGe}$ 上に成長させて引張りひずみを導入した $\mathrm{Si}$ (ひずみ $\mathrm{Si}$ )では電子の移動度が向上することを利用した FET 型デバイスが開発されている. Si 結晶で開発された Silicon on Insulator (SOI) 技術を使った SiGeOI の開発も報
告されている.このようなデバイスの一部は今日高速, 低消 費電力, 低ノイズの特徵から携帯電話や GPS へ利用されて いる. また，バルク状の $\mathrm{SiGe}$ 結晶は高温での大きな熱電能 と低い熱伝導率のために, Voyager や Cassini などの外惑星 探査機の電源用熱電素子として優れた実績がある. また, 高 品質の単結晶は $\mathrm{X}$ 線や中性子線用のモノクロメータやその 高感度検出器, 界面でミスフィット転位が発生しない, 薄膜 成長用のひずみフリー基板, そして太陽電池への利用が期待 されている。

SiGe をそれら応用へ展開するための基盤となる固有の物 性については，その組成に依存した興味深い結果が報告され ている(1).しかしながら，良質の結晶が得られていないた め, 未解明ないし不確実な点が多い。ここで, 基礎研究を行 う上では, 薄膜ではなく, ある大きさを持ったバルク状の高 品質結晶が不可欠である. またその基礎研究によって, この $\mathrm{Si}$ と Ge が完全に固溶した特異な結晶の潜在する特性を明ら かにすることができ, $\mathrm{SiGe}$ の高性能化と応用につながるの でないかと考える.

我々はこの $\mathrm{SiGe}$ の基礎的物性を解明し，その潜在的ポテ ンシャルを探索することを目的として, 高品質バルク結晶を 育成することを行った．さらにそれらを用いて，その特異な 局所構造, キャリア移動や熱伝導, 転位運動等の基礎的物性 の解明を進めた (2)(3).ここでは, 結晶育成と解明された基礎 物性のいくつかについて紹介する.

\section{2. バルク結晶の育成}

\section{（1）育成結晶}

全率固溶体である $\mathrm{SiGe}$ はその平衡状態図で分かるように

* 東北大学教授; 金属材料研究所 (

Growth and Fundamental Properties of SiGe Bulk Crystals; Ichiro Yonenaga(Institute for Materials Research, Tohoku University, Sendai)

Keywords: silicon-germanium, solid solution, bulk crystal growth, fundamental properties, atomistic structure, carrier mobility, impurity 2007 年 1 月 9 日受理 
液相線と固相線が大きく離れてその分配係数が 2 から 5 と, 1 より大きいため, 組成的過冷却が容易に発生し多結晶化し やすいとされている，実際，1990年代半ばにドイッやアメ リカのグループが試みた(4)-(14)が, 純 $\mathrm{Si}$ ないし Ge に近い組 成での単結晶の育成に限定され，バルク状の単結晶の育成は 容易ではなかった。我々のグループは一般的なチョクラルス キー法を用いて，その育成速度を $1-8 \mathrm{~mm} / \mathrm{h}$ と非常に遅く することで単結晶化を可能とした(2)(3)(6)(10)(11).

図 1 は Si 成分の多い SiGe 単結晶の育成例である.いず れの結晶も種結晶として[001]方位の Si 結晶を用いて育成し ている. 中央の結晶 (b) は初期組成 ( $\mathrm{Si}$ 組成) $x_{\mathrm{m} 0}=0.69$ の融 液から $2 \mathrm{~mm} / \mathrm{h}$ で育成したもので, 結晶の育成開始部分の 組成は $x_{0}=0.85$ で, 結晶終端部では $x_{\mathrm{f}}=0.82$ である. 左の 結晶 (a) は $\mathrm{Si}$ 組成が低い, $x_{\mathrm{m} 0}=0.39$ の融液加ら育成速度 1 $\mathrm{mm} / \mathrm{h}$ で育成した結晶で, 育成開始部分での組成が $x_{0}=0.73$

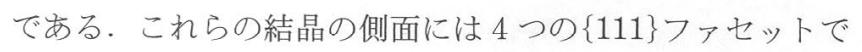
作られる結晶線と呼ばれる筋があり, 終端部なで単結晶とな っていることが確認される. 同じように $\mathrm{Ge}$ 成分の多い SiGeについても単結晶育成を行った。 そして, これまで に, 組成 $x$ が 0 から 0.2 までの $\mathrm{Ge}$ 成分の多い結晶扔よび 0.73 から 1 までの Si 成分の多い結晶で直径約 $15 \mathrm{~mm}$, 長さ 30

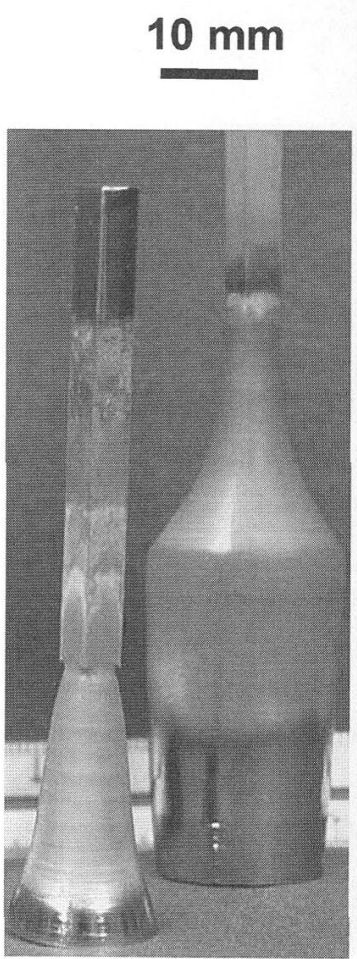

(a)

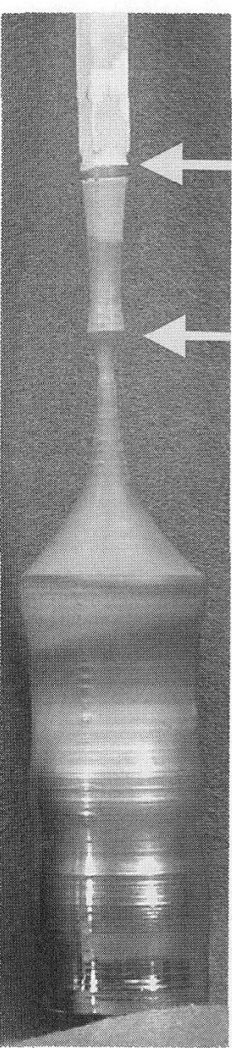

(c)
図 1 育成した SiGe 単結晶例。（a）育成開始部分の Si 組成が $x_{0}=0.73$, (b) $x_{0}=0.85$ の結晶. (c) 種結 晶に SiGe を用いて育成した SiGe 単結晶. 図中 の上側の矢印が $\mathrm{Si}$ 種結晶と $\mathrm{SiGe}$ 種結晶 ( $\mathrm{Si}$ 組 成: $x=0.95)$ の境界, 下側の矢印が $\mathrm{SiGe}$ 種結晶 之 $\mathrm{SiGe}$ 育成結晶 $(x=0.95)$ の境界位置である。な お,この結晶ではさらに無転位化のためのダッシ ュ・ネッキングを試みた。 $\mathrm{mm}$ 以上の単結晶を得ている。ささらに, 組成 $x$ が 0.8 か 1 の $\mathrm{Si} リ ッ チ の$ 組成領域では直径約 $25 \mathrm{~mm}$, 長さ $70 \mathrm{~mm}$ 以 上の大型の低転位密度の単結晶も得られた (3)。ただ，中間の 組成では数 $m m$ の小さな単結晶に限られる.

さらに，Si 組成 $x$ が 0.85 以上ではあるが，各種の電荷不純 物を添加し， $\mathrm{n}$ 型と $\mathrm{p}$ 型の結晶として育成することも試み, 直径約 $25 \mathrm{~mm}$, 長さ $70 \mathrm{~mm}$ 程度の導電性結晶を得ることが できた(15)(16)。

図 2 (a) は $\mathrm{Si}_{0.73} \mathrm{Ge}_{0.27}$ の結晶から育成軸に垂直に切り出し た断面ウェハーの X 線回折像である。同心円状に観察され るイメージは育成結晶中に発達した成長縞で, 組成のわずか な変動(ひずみとして $10^{-4}-10^{-3}$ 程度)があることを示す。 (b) $\mathrm{Si}_{0.98} \mathrm{Ge}_{0.02}$ の結晶について, 種結晶から育成が開始さ れた直後の部分の綎断面試料の X 線回折像である. 横縞は 成長縞でめるが, 斜めに伸びた白い線は種結晶を融液に浸し て先端を融解させる際に熱衝撃ないし熱応力によって発生し た転位像であり, 一方種結晶との界面から発生し, 成長軸に 沿って真っ直ぐに伸びる線は種結品 $\mathrm{Si}$ と育成した $\mathrm{SiGe}$ 固 溶体の格子定数差に起因するミスフィット転位のイメージで ある、種結晶との組成差は $2 \%$ であが， $5 \times 10^{-5}$ 以上のひ ずみであるためミスフィット転位の発牛は避けられない。育 成結晶に含まれる転位密度は組成に依存するが， $10^{3}-10^{5}$ $\mathrm{cm}^{-2}$ である。

\section{（2）単結晶育成のための条件}

\section{(a) 種結晶}

SiGe 固溶体をチョクラルスキー法で育成するための種結 晶として，[001]ないし $[111]$ 万位の $\mathrm{Si} と \mathrm{Ge}$ 結晶を用い た.これは異種シーディングであるが, 特徵として, Si 種 結晶で $\mathrm{Ge}$ 結晶(㛜密には, 種付け時の $\mathrm{Ge}$ の融解混入による 希薄固溶体)を育成することができた(17)。このことは Si 結 晶を種結晶として全組成域の SiGe 固溶体の育成に利用する ことができることを意味する，たた，種結晶と育成固溶体結 晶の界面で急峻な組成の変化があり，それが育成を困難にす

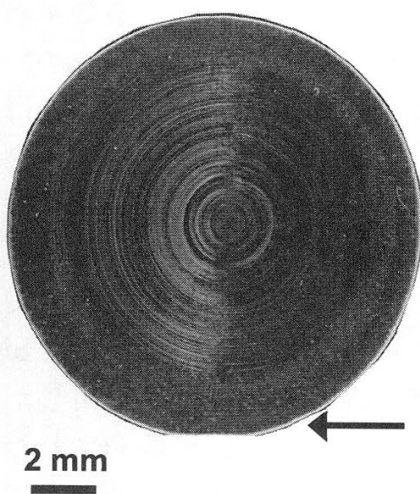

(a)

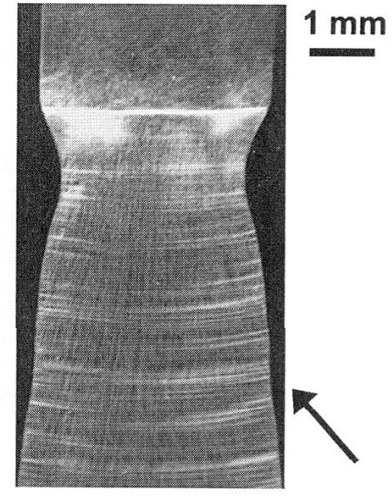

(b)
図2 育成した SiGe 単結晶のX線回折像. (a) Si 組 成: $x=0.73$ の結晶から育成軸に垂直に切り出し た断面ウェハー，（b） $x=0.98$ の結晶について， 種結晶から育成が開始された直後の部分の縦断 面試料. 図中の矢印は回折べクトル $g=220$. 
る.とりわけ，中間組成の固溶体結晶では組成的過冷却の発 生をいっそう誘起する。これを考慮して, 育成した SiGe 結 晶を種結晶として使うと, 育成結晶との界面での組成ずれを 避け，さらに前述の格子定数のミスマッチによる転位の発生 を抑制することができる。加えて，いわゆるダッシュネッキ ングを行うと, 結晶の低転位密度化や無転位結晶育成に有效 である。その試みの例を図 1 (c)に示す ${ }^{(3)}$.

\section{(b) 育成速度}

全率固溶体の育成に扑いて，その育成速度の適切な選択は 組成的過冷却による多結晶化を避けて単結晶を育成する上 で, キーとなる.図 3 は結晶育成速度 $v$ と組成 $x$ の関係につ いて, 本研究で実際に単結晶化できたか否かの結果を示 す(3). 組成的過冷却による多結晶化を避忊る条件として, 次 の Tiller らの関係式(18)に基づいて予測される成長速度 $v_{\mathrm{c}}$ と 較べると，実験的にはその速度よりさらに遅くする必要があ ると判断される。

$$
v_{\mathrm{c}}=D \nabla \Theta k / \nabla T_{1} x(k-1), \quad(k>1)
$$

ここで， $k$ は分配係数， $D$ は融液での溶質の拡散係数， $\nabla \Theta$ は融液での温度勾配， $\nabla T_{1}$ は液相線の傾きである。図 3 から さらに, 中間組成の結晶では, 育成速度が $1 \mathrm{~mm} / \mathrm{h}$ という 条件でも単結晶育成に関しては厳しいことが分かる。実際， 単結晶としてスタートしても途中で容易に多結晶化する。そ の観点で, $0.5 \mathrm{~mm} / \mathrm{h} の$ 育成速度で育成した中間組成の $\mathrm{Si}_{0.5} \mathrm{Ge}_{0.5}$ の結晶を図 4 に示す。（なお，この結晶は.2-3 枚の 双晶を伴うが，それらを避けて切り出した単結晶部分は後述 する物性測定には十分な大きさであった。）

\section{（3）育成結晶の特徵}

(a) 組成の変化

先述のように, SiGeに抽い Si は大きな分配係数を持 つ、そのため融液中の Si 成分が固化する結晶へ優先的に消

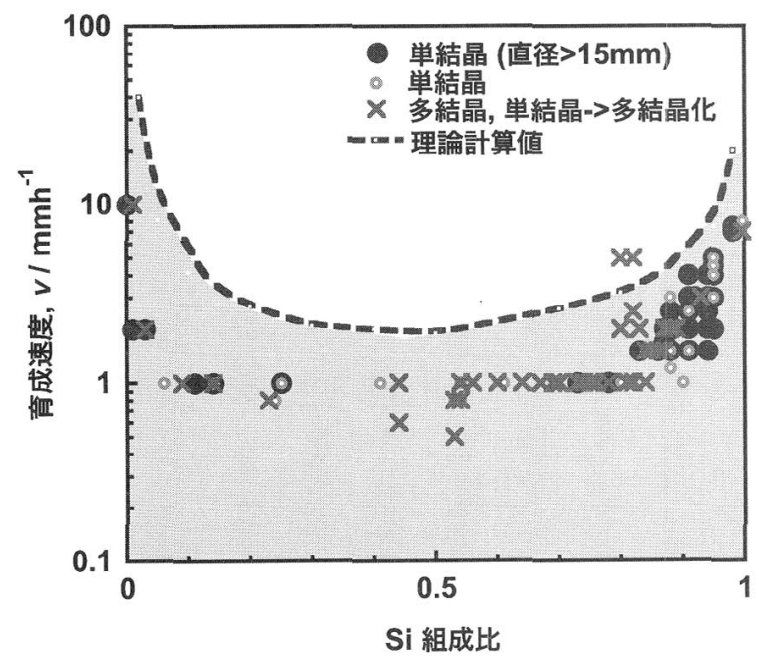

困 3 単結晶を育成するための結晶育成速度 $v$ と $\mathrm{Si}$ 組 成 $x$ の関係 ${ }^{(3)}$. 図中の丸印は単結晶の育成を，黒 丸はそのうちで直径 $15 \mathrm{~mm}$ 以上の結晶の育成を 示す。×印は多結晶の育成老，ないし単結晶から 育成後すぐに多結晶になったことを示す。破線は， Tiller らの関係式(18)に基づいて予測される組成 的過冷却による多結晶化が起きる臨界成長速度.
費されて融液中の Si 量が先に減少し, 結果として育成され る結晶も育成に伴って $\mathrm{Si}$ 組成が減少し, Ge 組成が増加する。 SiGe 固溶体の組成が㕕成軸に沿って変化する挙動は定性的 には融液が十分に擋拌されることを仮定した後述のPfann の関係によって記述される(19)。ただ, 中間組成の結晶で は, 育成された結晶の Si 組成ぶ特に育成開始部分ではあら かじめ予測された組成より高くなる傾向があり, その理由と して融液内での Si と Ge の比重差による影響が推定される.

\section{(b) 溶質·不純物偏析}

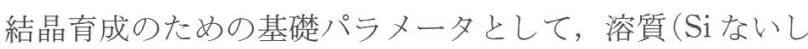
$\mathrm{Ge}$ ) や不純物の分配係数 (偏析係数) はその濃度を制御して添 加し各種の素子として利用するための電子機能材料設計上, 不可欠であるが，今回良質の単結晶が育成されたことで，精 度ある值を決定することが可能となった。

図 5 は各種の不純物を添加して育成した SiGe 固溶体結晶 (初期組成 $x_{\mathrm{m} 0}=0.90$ の融液から $2 \mathrm{~mm} / \mathrm{h}$ で育成 : 育成開始 部の組成 $\left.x_{0}=0.95\right)$ に打いて, その不純物濃度 $x$ が結晶の育 成率(固化率 $g$ )に対してどのように変化しているかを示した ものである，各種の不純物濃度は育成とともに増加すること が分かる。また，電荷不純物として重要な B や P は $10^{20}$ $\mathrm{cm}^{-3}$ の高濃度まで添加できる。 その固化率に対する不純物 濃度の変化は融液内では完全に撹汼された良好な混合状態が 達せられていることを仮定したPfannの関係によって記述

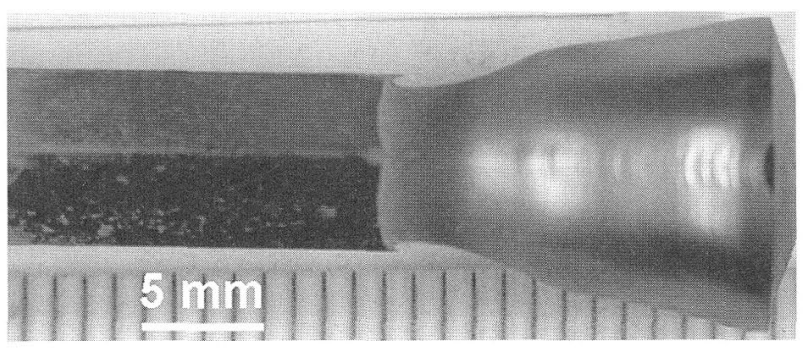

図 4 中間組成の $\mathrm{Si}_{0.5} \mathrm{Ge}_{0.5}$ の)結唱.

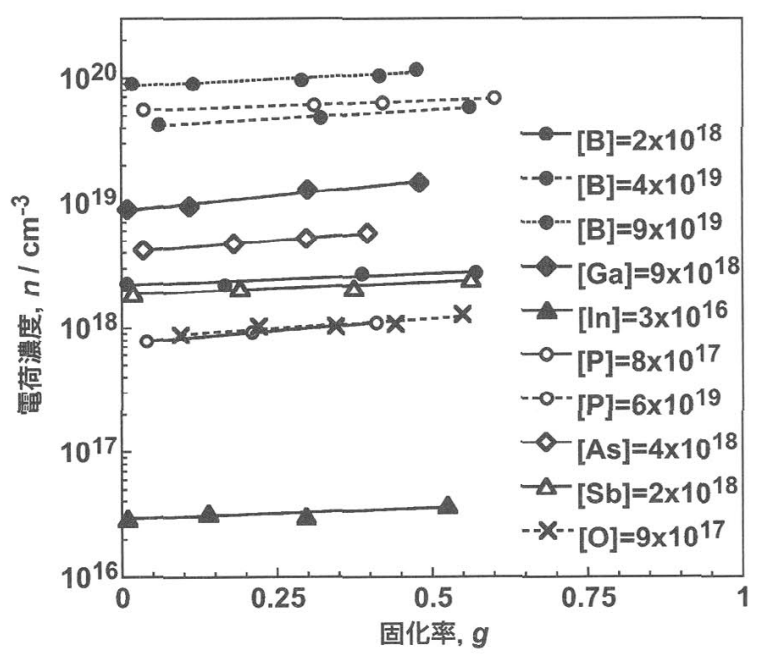

図 5 各種の不純物を添加して育成した SiGe 結晶(育 成開始部の Si 組成 $\left.x_{0}=0.95\right)$ での，各不純物濃度 の結晶の成長に伴う変化 ${ }^{(16)}$. 成長の度合いを固 化率 $g$ で表す. 
表 1 各種の不純物の分配係数(16). 比較のために，そ れら不純物の Si 結晶と $\mathrm{Ge}$ 結晶における分配係 数の文献値 ${ }^{(20)}$ と共有結合半径 ${ }^{(21)}$ を示す.

\begin{tabular}{lllcc}
\hline \hline 不純物 & in $\mathrm{Ge}^{(20)}$ & in $\mathrm{Si}^{(20)}$ & $\begin{array}{c}\text { in } \mathrm{SiGe} \\
\left.\text { (不純物濃度 }: \mathrm{cm}^{-3}\right)\end{array}$ & $\begin{array}{c}\text { 共有結合半径 } \\
(\mathrm{nm})^{(21)}\end{array}$ \\
\hline $\mathrm{B}$ & & 0.8 & $\begin{array}{c}0.71\left(2 \times 10^{18}\right) \\
0.58\left(4 \times 10^{19}\right)\end{array}$ & 0.088 \\
& & & $0.61\left(9 \times 10^{19}\right)$ & \\
\hline $\mathrm{Ga}$ & 0.087 & 0.008 & $0.18\left(9 \times 10^{18}\right)$ & 0.126 \\
\hline $\mathrm{In}$ & 0.01 & 0.0004 & $0.72\left(3 \times 10^{16}\right)$ & 0.144 \\
\hline $\mathrm{P}$ & 0.08 & 0.35 & $0.31\left(8 \times 10^{17}\right)$ & 0.110 \\
\hline $\mathrm{As}$ & 0.02 & 0.3 & $0.33\left(4 \times 10^{18}\right)$ & 0.118 \\
\hline $\mathrm{Sb}$ & 0.003 & 0.023 & $0.69\left(2 \times 10^{18}\right)$ & 0.136 \\
\hline $\mathrm{O}$ & & 1.4 & $0.54\left(9 \times 10^{17}\right)$ & - \\
\hline $\mathrm{Ge}$ & & 0.33 & 0.51 & 0.122 \\
\hline $\mathrm{Si}$ & & & & 0.117 \\
\hline
\end{tabular}

することができる(3)(16)(19).

$$
x(g)=x_{\mathrm{m} 0} k(1-g)^{k-1} .
$$

固化率に対する不純物濃度の変化の勾配から不純物の(実効) 分配係数 $k$ を決定することができる. 一般的に, 蒸気圧が高 い不純物 ( $\mathrm{SiGe}$ 固溶体の場合 $\mathrm{B}$ 以外の $\mathrm{P}$ や $\mathrm{Ga}$ など) を結晶 中へ添加する場合, その融液への初期添加量が正確に把握で きず初期融液組成が分からないために分配係数の決定は容易 ではないが，この方法では初期添加量によらずに分配係数を 決定できる.

表 1 は各種の不純物について決定した分配係数をこれまで 報告されている $\mathrm{Si}$ 結晶と Ge 結晶における值と比較して示 す(16)(20). また, B と P 不純物については異なる濃度条件で の結果も示す. 特徵として, Si 結晶での結果と比較すると, Ge がわずか $5 \%$ の固溶ではあるが, 不純物の分配係数は大 きく変化することが分かる. とりわけ，原子サイズ(21)に注 目すると, 原子サイズの大きな不純物 $\mathrm{Ga}, \mathrm{In}, \mathrm{Sb}$ では $\mathrm{Si}$ 結 晶での值から 1-3 桁大きくなり, P P B などの分配係数と 同じレベルに達している．これに対して原子サイズが同等の 不純物では変化は少なく, 原子サイズが小さい B ではその 濃度が増加すると, 分配係数の低下が起きる(3)(16). 原子サ イズの大きな不純物は $\mathrm{Ge}$ と置換するが， $\mathrm{Ge}$ の固溶によっ て格子定数が増加し, その結果として SiGe 中に固溶しやす くなり, 一方, Si と置換する原子サイズの小さな $\mathrm{B}$ は, 固 溶体の格子定数が増加するためにひずみエネルギーが増加し て固溶できにくくなると推定される.この結果は, 従来分配 係数が非常に小さいために Si 中へ均一に固溶させることが 容易ではないとされる不純物を固溶させる上で, 有効な方法 として応用上興味深い。

\section{3. 基 礎 物 性}

高品質のバルク単結晶が得られたことで, その基礎物性を 評価することが可能となった。ここでは海外の基礎研究グル

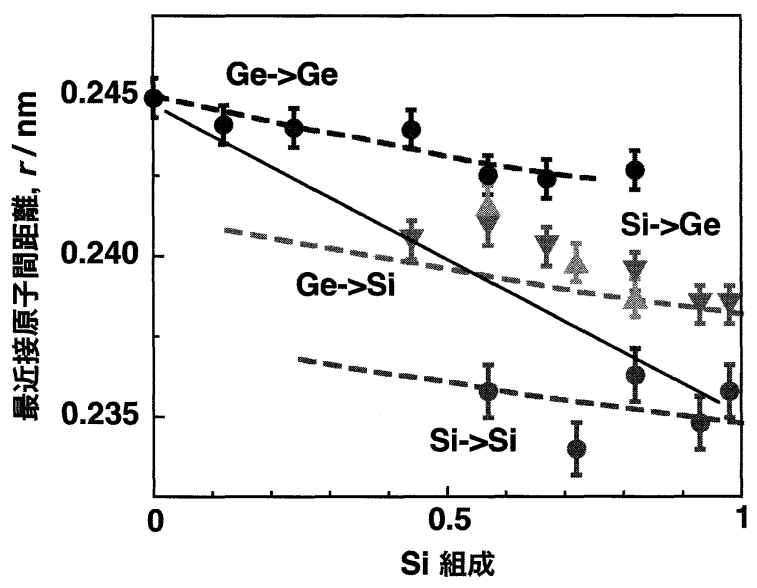

図6 $\mathrm{SiGe}$ 固溶体における $\mathrm{Ge}-\mathrm{Ge}, \mathrm{Ge}-\mathrm{Si}, \mathrm{Si}-\mathrm{Si}$ の各 原子対の結合距離の組成依存性 ${ }^{(24)}$. 図中の点線 は第一原理計算によって予測される各原子対の 結合距離の組成に対する依存性 ${ }^{(25)}$. 中央の細線 は巨視的に決定される格子定数の組成に対する 依存性である(22).

一プとの共同研究の成果も含め, そのいくつかの結果を述べ る.

\section{（1）固溶体の局所構造}

$\mathrm{SiGe}$ 固溶体の格子定数はその組成によって $\mathrm{Si}$ から $\mathrm{Ge}$ へ ほぼVegard 則に従って変化する ${ }^{(22)}$ 。しかしながら，その 局所構造については，良質のバルク結晶がないために詳細は 確立されていなかった。

本研究では育成した各種組成の $\mathrm{SiGe}$ 固溶体の局所的構造

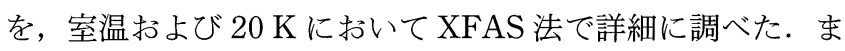
ず，原子配置について，その配位数はダイヤモンド構造にお ける基本である合計 4 を全ての組成範囲で維持し，さらに 各配位数の組成依存性から, Si と Ge の原子の配置は完全に ランダムであることを見いだした．そして，原子配置におい ては短範囲，長範囲ともに規則性がないことも分かった。薄 膜 $\mathrm{SiGe}$ で報告されていた規則構造の発達はへテロエピタキ シャル成長時のひずみが関与することを示唆する，一方，原 子間の結合距離について, $\mathrm{Ge}-\mathrm{Ge}, \mathrm{Si}-\mathrm{Ge}, \mathrm{Si}-\mathrm{Si}$ の各原子対 の結合距離は図 6 に示すように，同一でなく，それぞれ異な るが，それらの結合距離は組成に対してほぼ同じ勾配で線形 に変化することが得られた ${ }^{(23)(24)}$.これらの実験結果は, Sluiter らが行った第一原理計算に基づく電子構造のシミュ レーションでの, $\mathrm{Ge}-\mathrm{Ge}, \mathrm{Si}-\mathrm{Ge}, \mathrm{Si}-\mathrm{Si}$ の各原子間の結合距 離の組成に対する依存性と良好に一致する ${ }^{(25)}$ 。これらの結 果から，この全率固溶 SiGe 固溶体は不完全ではあるが，い わゆるポーリング型の構造 ${ }^{(26)}$ ，すなわち結合ボンド長と結 合角が同時に変化する特異な構造であることが明らかになっ た. 図 7 はこれらの結果から推定される原子構造を模式的に 示す ${ }^{(24)}$. 基本的には $\mathrm{Si}-\mathrm{Si}-\mathrm{Si}$ の組み合わせではその結合角 が増加し，逆に Ge-Ge-Ge では減少する．また， Si-Si の結 合距離はマクロに観察される格子定数より縮んでおり, 逆に $\mathrm{Ge}-\mathrm{Ge}$ では伸びている.

ここで, 不完全ポーリング型構造は GaInP などのIII-V族 


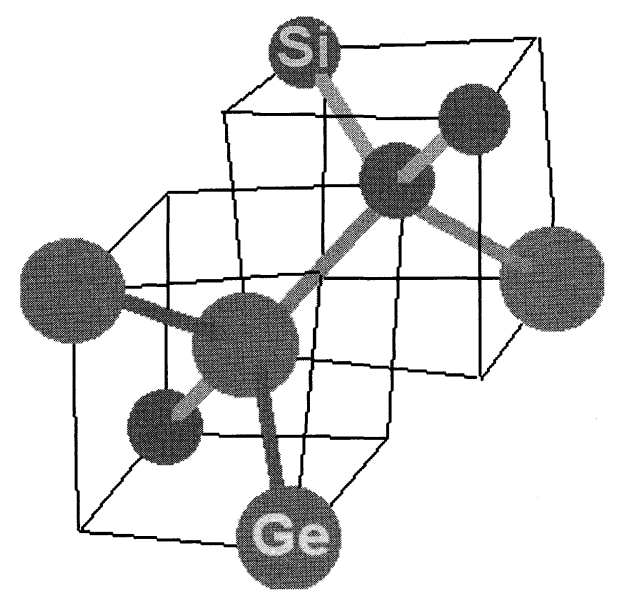

図 7 SiGe 固溶体の原子構造の模式図 ${ }^{(24)}$.

やII-V族全率固溶体でも報告されている（例えば文献(27)) が，例えばIII-V混晶ではIII族原子と V 族原子がそれぞれの 副格子に配置されるという拘束が， SiGeにはないという観 点で, 完全にランダムな原子配列の不完全ポーリング型構造 の固溶体であることを強調したい.

\section{（2）キャリアの移動度}

半導体材料において，キャリア濃度と移動度は各種素子の 設計という実用上もっとも重要なパラメータであるが，これ までは多結晶を使って測定された古い結果(28)(29) がそのまま 使われてきた．今回高品質の単結晶が得られたことで，その 古いデータを再検討することが可能となった． また，その散 乱機構の検討を行った。ここでは育成した結晶を用いて室温 から $800^{\circ} \mathrm{C}$ までホール係数測定により決定した結果について 述べる.

電子とホールの移動度が結晶の組成 $x$ に対してどのように 依存するかについて，不純物を添加しない結晶(室温でのキ ヤリア濃度 $4 \times 10^{15} \mathrm{~cm}^{-3}$ 以下)の, 室温での結果を図 8 に示 す。多結晶試料の結果と較べると，粒界面の影響が全くない ため, 約 $20 \%$ 程度高い值である. 電子の移動度のデータは Si リッチの組成 $x=0.8-1$ の範囲に限られる.これは $\mathrm{SiGe}$ の育成に掠いて， $x=0-0.8 て ゙ は 0.8-1$ のものと同じ素材を 利用しても $\mathrm{p}$ 型が育成されるためである。 その理由は固有 点欠陥の影響と思われるが，詳細な検討が必要である.

$\mathrm{SiGe}$ でのキャリアの移動度は Si と Ge に較べると著しく低 下し，中間組成で，少なくともホールの移動度は $\mathrm{Si}$ 組成 0.7-0.8付近で最小值 $260 \mathrm{~cm}^{2} / \mathrm{Vs}$ を示す。このような，ほぼ Nordheim 則に従う理由は，この結晶が前述のように無秩序 な固溶体であるために各原子位置でのポテンシャルが摇ら ぎ，その結果としてキャリアの移動が散乱される，いわゆる alloy scattering が関与しているためであると考えられる. このことは後述する熱伝導度が組成に対し $x(1-x)$ 型の依存 性を示し，中間組成でミニマムとなることからも推察される.

図 9 は電荷不純物を固溶する $\mathrm{Si}$ 組成が $x=0.93-0.96$ の結 晶について, 室温での電子とホールの移動度の不純物濃度に 対する依存性を示す ${ }^{(30)}$. 不純物として, $\mathrm{n}$ 型では $\mathrm{P}, \mathrm{As}, \mathrm{Sb}$ を添加し，一方 $\mathrm{p}$ 型では B, In を添加しているが，不純物種



図 8 単結晶 $\mathrm{SiGe}$ 固溶体での電子とホールの室温での 移動度の $\mathrm{Si}$ 組成 $x$ に対する変化．比較のために 多結晶試料での結果も示す。

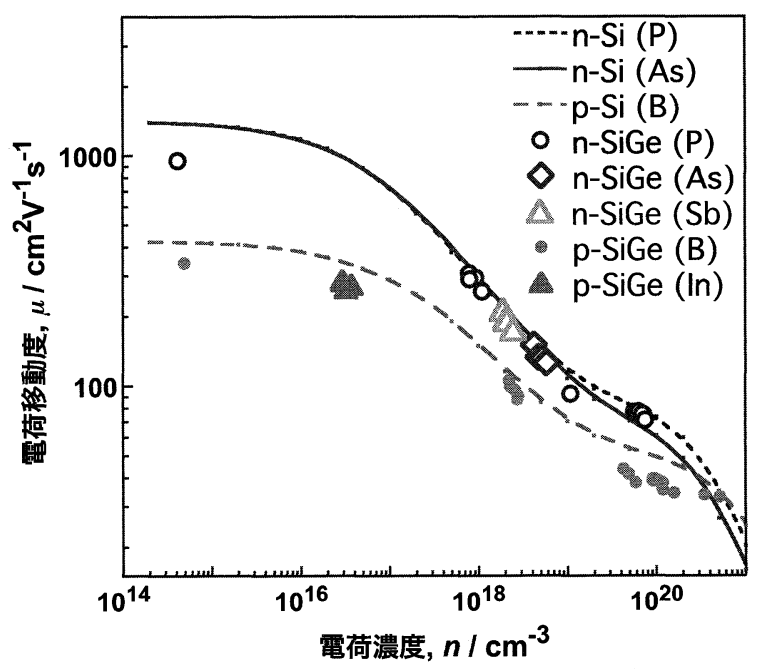

図 9 不純物を添加した $\mathrm{Si}$ 組成 $x=0.93-0.96$ の $\mathrm{SiGe}$ 固溶体での，室温における電子とホールの移動 度の不純物濃度に対する依存性 ${ }^{(30)}$ 。図中に不純 物種を，また実戦と破線で Masetti らによるn 型 と $\mathrm{p}$ 型の $\mathrm{Si}$ 結晶における結果を示す ${ }^{(31)}$.

の違いによる影響は見いだせない，不純物濃度の増加につれ てキャリアの移動度が低下する特徵は, Si 結晶での結果と 非常によく類似している(31). 不純物を添加していない結晶 ないし不純物濃度の低い結晶では，室温での電子移動度は $\mathrm{Si}$ 結晶の1500から $900 \mathrm{~cm}^{2} / \mathrm{Vs}$ へ，またホール移動度は 450 から $350 \mathrm{~cm}^{2} / \mathrm{Vs}$ へと明瞭に低下するが，不純物濃度 $10^{18}$ $\mathrm{cm}^{-3}$ 以上ではその差異はあまり明確ではない。これはキャ リアの散乱過程が; 不純物濃度が高い結晶では前述の alloy scattering とともに，電荷不純物による charged impurity scatteringによっても支配されていることを示唆する．その 過程は，不純物を高濃度で固溶する導電性の結晶ではキャリ アの移動度の温度に対する低下が不純物を添加しない結晶に 較べて緩やかであること, また熱電能(Seebeck 係数)の電気 伝導度依存性からも指示される(32)(33). 
さて, $\mathrm{Si}$ や $\mathrm{Ge}$ などの典型的な半導体では, 不純物濃度, キャリア移動度, 比抵抗值の関係が確立され, 室温での比抵 抗測定值から結晶中の不純物濃度を推定するための簡便な関 係として，いわゆるIrvinの曲線(34) が確立され，重宝され ている. SiGeではこれまでそれらの関係が明らかにされて いなかったが，今回 $\mathrm{Si}$ 組成0.93-1の範囲ではあるが，その Irvin 曲線を求めることができた ${ }^{(30)}$ 。この関係を使うこと で，比抵抗測定值からキャリア濃度が推定できるため, Hall 係数測定を経ずに種々の議論を進めることが容易になること が期待される。

\section{（3）熱伝導}

$\mathrm{SiGe}$ バルク結晶は $500-800^{\circ} \mathrm{C}$ 温度域の熱電材料として注 目されるため，その基礎知識として前述のキャリア移動度， 熱電能, そして熱伝導度を調べた。図10は不純物を添加しな い結晶での，室温と $600^{\circ} \mathrm{C}$ での熱伝導率の $\mathrm{Si}$ 組成 $x$ に対する 依存性を示す。どちらの温度でも，中間組成 $x=0.5-0.7$ で ミニマムとなる $x(1-x)$ 型の組成依存性が得られる. 熱伝導 度は温度の上昇とともに低下し，その温度依存性は中間組成 の結晶では $T^{0.4}$ で記述される ${ }^{(35)}$. 不純物の添加によってフ オノンが散乱されるため, 熱伝導度は徐々に低下するが, $10^{19} \mathrm{~cm}^{-3}$ 以上の高濃度の結晶になると，そのキャリアによ る伝導が加わるために，トータルの熱伝導度の増加が認めら れた(32).

先述のこの材料がランダムな原子配列の不完全ポーリング 型構造の固溶体であるという観点で, その熱伝導特性は基礎 的に興味深い。応用上その原子サイズ差に較べてはあまり注 目されないことであるが，この $\mathrm{SiGe}$ 固溶体は構成する成分 元素の質量比 $(\mathrm{Ge} / \mathrm{Si})$ が 2.3 と非常に大きく, そのため熱伝導 度が低温で著しく低く, また特異な温度依存性を示す(36). また，これらの特徵はガラスと類似しており，そのためガラ 不質材料の構造と特性を研究するための格好の材料であるこ とが期待されている. 現在, 中間組成の固溶体でのフォノン 分散等による研究が進行中である.

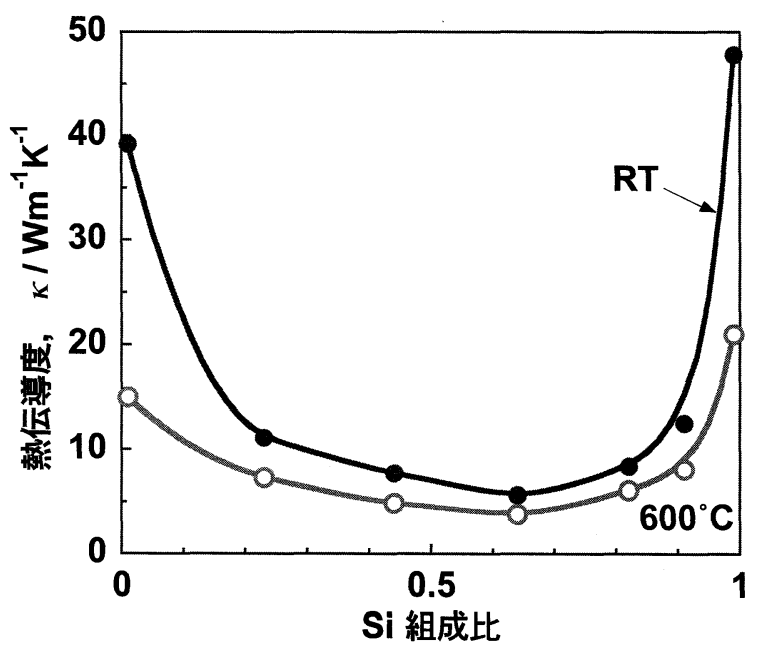

図10 不純物を添加しない $\mathrm{SiGe}$ 固溶体での，室温と $600^{\circ} \mathrm{C}$ における熱伝導率の $\mathrm{Si}$ 組成 $x$ に対する依存 性.

\section{（4）酸素·水素不純物}

$\mathrm{Si}$ 結晶における主要な不純物である酸素は結晶育成時に おける石英るつぼと融液との反応により結晶中に混入する が，石英るつぼを使用する $\mathrm{SiGe}$ 固溶体においても同様であ る。不純物酸素は $\mathrm{Si}$ 成分の多い組成では育成結晶中に最大 濃度 $10^{18} \mathrm{~cm}^{-3}$ で固溶する. SiGe 固溶体においては $\mathrm{Si}-\mathrm{Si}$ ボンド間に位置する O 原子は Si-O-Si 準分子として 1106 $\mathrm{cm}^{-1}$ において固有振動を示すが， $\mathrm{Ge}-\mathrm{O}-\mathrm{Ge}\left(855 \mathrm{~cm}^{-1}\right)$ とそ れらの中間にあると思われる $\mathrm{Ge}-\mathrm{O}-\mathrm{Si}$ に起因する固有振動 は，ともに検出されない(図11)(37)。これは酸素不純物が $\mathrm{Si}-$ $\mathrm{Si}$ 結合の原子間位置を選択的に占め, $\mathrm{Si}-\mathrm{Ge}, \mathrm{Ge}-\mathrm{Ge}$ 結合間 には存在しないことを意味する．そして，それが $\mathrm{Si}$ とOの 結合力が $\mathrm{Ge}$ と $\mathrm{O}$ に較べて強いため $\left(\mathrm{SiO}_{2}: 9.9 \mathrm{eV}, \mathrm{GeO}_{2}\right.$ : $6.5 \mathrm{eV})^{(38)}$ であることが明らかになった。このことは結晶中 に固溶する酸素濃度が固溶体の $\mathrm{Si}$ 組成に対して 2 乗で変化 することからも示唆された。また，固有振動のピーク位置は 固溶体の組成が Si リッチから Ge リッチに变化するにつれ て低振動数側へシフトする. そのシフト量は格子定数の変化 ではなく, 前述の Si-Si 結合距離の变化と良好に対応する.

酸素と並んで重要な不純物である水素はその高い反応性の ために特性を解明する上で多くの困難を伴うが，我々は水素 の同位体であるミュオニウムを使った評価をすすめた．Si や $\mathrm{Ge}$ ではミュオニウの占有位置として四面体格子間位置 (正常ミュオニウム) と結合ボンド間の中間位置(異常ミュオ ニウム) とが知られているが， $\mathrm{SiGe}$ 固溶体でも同じである が，図12に示すようにボンド間位置のミュオニウムの微細相 互作用パラメータが組成に対して線形に変化することに対し て，四面体格子間位置のミュオニウムではほぼ全組成域で $\mathrm{Si}$ 結晶に近い值を示すことが明らかにされた ${ }^{(39)}$. SiGe 固溶 体中での水素の配置や挙動にする示唆を与えるが，先述の原 子間結合特性と併せて, 理論的検討を行う必要がある.

\section{4.おおりに}

格子定数，バンドギャップ制御工学材料として，また熱電

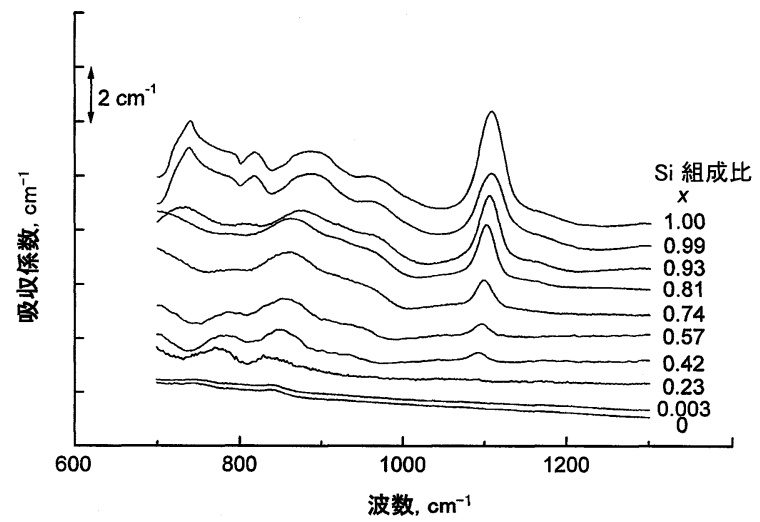

図11 SiGe 固溶体の室温における赤外吸収スペクト ル. 図中の数字は $\mathrm{Si}$ 組成を示す. $1106 \mathrm{~cm}^{-1}$ に $\mathrm{Si}-\mathrm{O}-\mathrm{Si}$ 準分子の固有振動ピークが観察され る(37). 


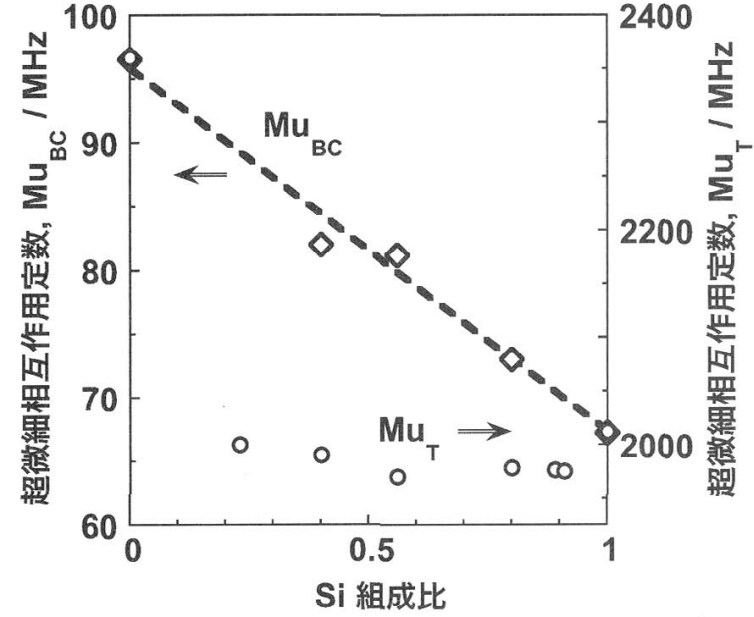

図12 SiGe 固溶休でのボンド間位置ミュオニウムと四 面体格子間位置ミュオニウムの微細相互作用パ ラメータの組成に対する依存性 ${ }^{(39)}$.

材料としても注目されている $\mathrm{SiGe}$ 半導体について，その応 用の基盤となる物性の解明を目的として, 高品質バルク結晶 を育成した。そして，その不完全ポーリング型と呼ばれる特 異な原子構造, キャリア移動度, 不純物挙動等の基礎的特性 を明らかにした。ただ，中間組成の SiGeの物性等について はデータが限られている，固溶体全組成域での知識の確立の ためには, 図 4 で示した小さな結晶の大型化やn型導電性 結晶の育成，なた固有点欠陥の特性解明など多くの課題が残 されている、さらに, 不完全ポーリング型の原子構造に基づ いた各種物性の理論的検討も必要である。

ここに紹介した典型的な二元全率固溶体の SiGe での成果 が他の固溶体等の材料系での開発の基礎知識となることを期 待する。

本研究の推進に当たり非常に多くの方々のご支援を頂い た. 特に, 結晶構造の決定に関して, 当研究所の櫻井雅樹博 土に厚く感謝する。

\section{文献}

(1) Properties of Silicon Germanium and SiGe: Carbon, ed. by E. Kasper and K. Lyutovich, INSPEC, London, (2000).

(2) I. Yonenaga: The Encyclopedia of Materials: Sicence and Technology, ed. by K. H. J. Buschow, R. W. Cahn, M. C. Flemings, B. Ilschner, E. J. Kramer and S. Mahajan, Elsevier Science, (2001), 8647-8651.

(3) I. Yonenaga: J. Crystal Growth, 275(2005), 91-98.

(4) A. Dahlen, A. Fattah, G. Hanke and E. Karthaus: Cryst. Res. Technol., 29 (1994), 187-198.

(5) M. Kürten and J. Schilz: J. Crystal Growth, 139 (1994), 1-5.

(6) I. Yonenaga, A. Matsui, S. Tozawa, K. Sumino and T. Fukuda: J. Crystal Growth, 154(1995), 275-279.

( 7 ) J. Wollweber, D. Schilz and W. Schröder: J. Crystal Growth, 158 (1996), 166-168.

(8) N. V. Abrosimov, S. N. Rossolenko, V. Alex, A. Gerhardt and W. Schröder: J. Crystal Growth, 166(1996), 657-662.

(9) K. Kadokura and Y. Takano: J. Crystal Growth, 171(1997),
56-60.

(10) A. Matsui, I. Yonenaga and K. Sumino: J. Crystal Growth, 183 (1998), 109-116.

(11) I. Yonenaga and M. Nonaka: J. Crystal Growth, 191(1998), 393-398.

(12) P. Dold, A. Barz, S. Recha, K. Pressel, M. Franz and K. W. Benz: J. Crystal Growth, 192(1998), 125-135.

(13) Y. Azuma, N. Usami, T. Ujihara, G. Sazaki, Y. Murakami, S. Miyashita, K. Fujiwara and K. Nakajima: J. Crystal Growth, 224 (2001), 204-211.

(14) M. P. Volz, M. Schweizer, N. Kaiser, S. D. Cobb, L. Vujisic, S. Motakef and F. R. Szofran: J. Crystal Growth, 237-239(2002), 1844-1848.

(15) I. Yonenaga: J. Crystal Growth, 226(2001), 47-51.

(16) I. Yonenaga and T. Ayuzawa: J. Crystal Growth, 297(2006), 14-19.

(17) I. Yonenaga and Y. Murakami: J. Crystal Growth, 191(1998), 399-404.

(18) W. A. Tiller, K. A. Jackson, J. W. Rutter and B. Chalmers: Acta Metall., 1(1953), 428-437.

(19) W. G. Pfann: J. Metals, 4(1952), 747-753.

(20) G. Möller and A. Ostrogorsky: Handbook of Crystal Growth, 2b, ed. by D. T. Hurle, North-Holland, Amsterdam, (1994), 709-819.

(21) J. C. Phillips: Bonds and Bands in Semiconductors, Academic, New York, (1973).

(22) J. P. Dismukes, L. Ekstrom and R. J. Paff: J. Phys. Chem., 68(1964), 3021-3027.

(23) I. Yonenaga and M. Sakurai: Phys. Rev. B, 64(2001), 113206.

(24) I. Yonenaga, M. Sakurai, M. H. F. Sluiter and Y. Kawazoe: J. Matcr. Sci.: Mater. Electron., 16 (2005), 429-432.

(25) M. H. F. Sluiter and Y. Kawazoe: Mater. Trans., 42(2001), 2201-2205.

(26) L. Pauling: The Nature of the Chemical Bond, Cornell University Press, Itahca, New York, (1967).

(27) J. C. Mikkelsen, Jr. and J. B. Boyce: Phys. Rev. Lett., 49 (1982), 1412-1415.

(28) Landolt-Börnstein, Vol. 17a and 22a, Springer, Berlin, (1982 and 1987).

(29) R. Braunstein: Phys. Rev., 130(1963), 869-879.

(30) I. Yonenaga: Jpn. J. Appl. Phys., 45 (2006), 2678-2679.

(31) G. Masetti, M. Severi and S. Solmi: IEEE Trans. Electron Devices, 30(1983), 764-769.

(32) I. Yonenaga, T. Akashi and T. Goto: Mater. Res. Soc. Symp. Proc., 691(2002), G7.4.1.

(33) I. Yonenaga, W. J. Li, T. Akashi, T. Ayuzawa and T. Goto: J. Appl. Phys., 98(2005), 063702.

(34) S. M. Sze: Physics of Semiconductor Devices (2nd.), Wiley, New York, (1981).

(35) I. Yonenaga, T. Akashi and T. Goto: J. Phys. Chem. Solids, 62(2001), 1313-1317.

(36) A. Béraud, J. Kulda, I. Yonenaga, M. Foret, B. Salce and E. Courtens: Physica B, 350 (2004), 254-257.

(37) I. Yonenaga, N. Fukata and M. Nonaka: Physica B, 308310 (2001), 539-541.

(38) D. C. Paine, C. Caragianis and A. F. Schwartzman: J. Appl. Phys., 70(1991), 5076-5084.

(39) P. J. C. King, R. L. Lichti, S. P. Cottrell, I. Yonenaga and B. Hitti: J. Phys.: Condens. Matter, 17(2005), 4567-4578.

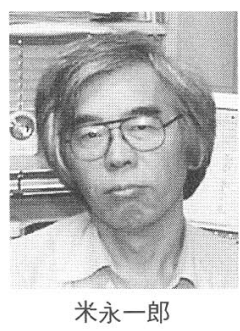

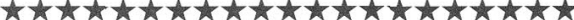
1980年 東北大学大学院工学研究科単位取得退学 1980年 東北大学金属材料研究所助手 1997年 東北大学金属材料研究所助教授 2006年 東北大学金属材料研究所教授 専門分野：焔構造·物性制御，混晶育成 $\mathrm{Si}, \mathrm{GaN}$ 等種々の材料に抢ける欠陌の構造と特性をマ ルチスケールで研究中, 転位・不純物との反応による 物性制御を進めている。 また，ここに紹介した SiGe 等の混晶半導体の創成とその物性解明を行っている。

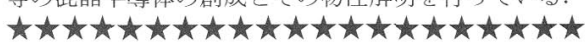

